\title{
3. ÉS 4. ÉVFOLYAMOS TANULÁSBAN AKADÁLYOZOTT GYEREKEK BESZÉDÉSZLELÉSÉNEK ÉS OLVASÁSTECHNIKÁJÁNAK ELEMZÉSE
}

Szerzők:

Kuncze Tímea

Győri Gárdonyi Géza Általános Iskola

(Magyarország)

Macher Mónika

Eötvös Loránd Tudományegyetem

(Magyarország)

Első szerző e-mail címe:

kuncze.timea@gmail.com
Lektorok:

Dankovics Natália

Debreceni Egyetem Gyermeknevelési és

Felnőttképzési Kar (Magyarország)

Szabó Edina

Debreceni Egyetem Gyermeknevelési és Felnőttképzési Kar (Magyarország)

Mezö Katalin

Debreceni Egyetem

Nemes Magdolna

Debreceni Egyetem

Kuncze Tímea, Marcher Mónika (2017): 3. és 4. évfolyamos tanulásban akadályozott gyerekek beszédészlelésének és olvasástechnikájának elemzése. Különleges Bánásmód, III. évf. 2017/3. szám, 87-107. DOI 10.18458/KB.2017.3.87

\begin{abstract}
Absztrakt
Jelen tanulmány a beszédfeldolgozás kiemelkedő szerepére fókuszál, melyet az olvasás és olvasástanulás folyamataiban tölt be. Jelentősége és aktualitása a gyógypedagógusok szemléletformáló hatásában áll, ugyanis a kutatás ráirányítja a figyelmet arra, hogy az egyes tünetek mögött valójában milyen okok húzódhatnak meg. A kutatásban arra kerestük a választ, hogy milyen összefüggések jelenhetnek meg 3. és 4. évfolyamos tanulásban akadályozott gyermekek beszédfeldolgozási és olvasási folyamatai között, kitérve az észlelés egyes területeinek, valamint a szöveg- és mondatértés egymáshoz viszonyított müködésére, továbbá a különböző olvasástechnikai szintekre. A célcsoport 26, míg a kontrollcsoport 25 főből állt. Mindkét területet sztenderdizált tesztekkel vizsgáltuk: a beszédészlelést a GMPdiagnosztikával, az olvasástechnikát pedig az osztályfoknak megfelelő Meixner-féle olvasólapokkal. Az eredmények a beszédfeldolgozás minden vizsgált szintjének súlyos elmaradását mutatják, mely az olvasás minőségében és a szövegértésben is jelentős nehézséget jelent. Mindez felhívja a figyelmet a prevencióra és a beszédészlelés tudatos fejlesztésének szükségességére az oktató-nevelö munkában.
\end{abstract}

Kulcsszavak: beszédfeldolgozás, olvasás, tanulásban akadályozottság

Diszciplina: pedagógia

Abstract

Current study focuses on the outstanding role of speech processing in the processes of reading and learning of reading. Its importance and actuality is the shaping attitude of the 
special needs teachers, because the study shows the causes of certain symptoms. We searched for the answer of the relationship between the speech and reading processes of 3rd and 4th grade children with mild intellectual disabilities. We touched upon the aspects of perception, the functioning of text comprehension compared with sentence comprehension and the different levels of reading. The experimental group consisted of 26 pupils and the control group consisted of 25 children. Both of the researched area were studied by standardized methods: the speech process was studied by GMP-diagnostics and the reading by the reading paper of Meixner. The results show the serious delay of development of every studied level of speech processing which causes remarkable difficulty in the quality of reading and reading comprehension. All these information draws attention to the necessity of prevention and the development of speech perception in the education.

Keywords: speech processing, reading, mild intellectual disabilities

Disciplines: pedagogy

A mai magyar társadalomban egyre kitüntetőbb szerep jut a gyógypedagógusoknak mind a szegregált, mind pedig az integrált iskolarendszerben, így egyre felelősebb pozíciót töltenek be főleg azoknak a többségi pedagógusoknak a szemléletének alakításában, akik integráltan foglalkoznak sajátos nevelési igényü gyerekekkel. A szemléletformálás azért is kiemelkedő fontosságú, mert az ő szerepük nagyobbrészt a tünetek felismerésére korlátozódik. Ahhoz azonban, hogy a megfelelö időben tudjanak szakemberhez fordulni, elengedhetetlen fontosságú, hogy tisztában legyenek az egyes tüneteket kiváltó okok széles skálájával és a nehézségek, elmaradások, zavarok okozta következményekkel, azok kapcsolódási pontjaival.

Jelen tanulmány azért tölt be fontos szerepet, mert felhívja a figyelmet a beszédfeldolgozás kiemelkedő szerepére az olvasás és olvasástanulás folyamatában. Mindezeken túl azt is megmutatja, hogy a sokszor emlegetett „figyelmetlenség” mögött valójában milyen okok és tünetek húzódhatnak meg.

A beszédészleléssel kapcsolatban viszonylag sok hazai és nemzetközi kutatás készült, a tanulásban akadályozott gyermekek populációját is beleértve. Azonban a populációt érintő, a beszédpercepció és az olvasás kapcsolatát vizsgáló szakirodalmak rendkívüli hiánya tapasztalható annak ellenére, hogy a két terület szoros kapcsolatát már évtizedekkel ezelőtt is hangsúlyozták a szakma képviselői (Nagy, 2004; Gósy, 2005; Csépe és tsai., 2007-2008a).

A vizsgálat eredményei a tanulásban akadályozott gyerekekkel foglalkozó pedagógusok, gyógypedagógusok munkáját kívánja segíteni bízva abban, hogy az anyanyelvi nevelés és a kommunikációs képességfejlesztés folyamatának megtervezéséhez releváns, iránymutató információkkal szolgál.

\section{BESZÉDÉSZLELÉS}

$\mathrm{Az}$ anyanyelv-elsajátítást két, egymással összefüggő folyamat befolyásolja: a beszédprodukció és a beszédészlelés, beszédmegértés. Az elsajátítás azonban különböző organikus, funkcionális, pszichés vagy környezeti okok miatt atipikussá válhat. Míg a beszédprodukció zavarainak felismerése könnyebb mind a szakemberek, mind a szülök számára, addig a beszédpercepciós zavaroké elhúzódhat akár kisiskolás, vagy még későbbi életkorig, hiszen ez a folyamat jóval rejtettebb, így megeshet, hogy elsiklanak felette, esetleg más probléma tüneteként azonosítják (Gósy, 2007a).

A beszédpercepció az észlelés speciális formája, a beszédészlelés és az olvasás a nyelvi észlelés két alapvető egysége. Lényegében a két különböző módon észlelt nyelvi információ 
értelmezése során ugyanarra az eredményre jutunk, a feldolgozás módja között mégis hatalmas különbség van (Csépe és tsai, 2007-2008a).

A beszéd feldolgozása két, egymással szoros kapcsolatban álló alfolyamatból áll, a beszédészlelésből, vagyis a hangjelenségek észleléséből és a beszédmegértésből, amely lehetővé teszi a kódrendszer értelmezését (Gósy, 2005 id. Csépe és tsai, 2007-2008a p. 22.).

A beszédmegértés hierarchikus felépítésű modelljében első lépésként a hallási feldolgozás szintjén végbemenő részfolyamatok lépnek müködésbe, melyek magukban foglalják az észlelésnek a beszédhangok, hangkapcsolatok, vagyis a beszéddel kapcsolatos információk felismerésének és azonosításának menetét. Az akusztikai-fonetikai szinten a beszéddel kapcsolatos beszédhangok környezettől való elválasztása történik, továbbá itt megy végbe az elkülönített hangok fonémaazonosítása is, amelyek egyfajta mentális reprezentációként szolgálnak. A fonológiai elemzés szintjén a beszédspecifikus feldolgozásról a nyelvspecifikus feldolgozásra helyeződik a hangsúly. Így egyfajta dekódolási folyamat során a beszédhangok lefordítása történik azok mentális reprezentációjára, vagyis a fonémákra. (Gósy 2005; Csépe és tsai, 2007-2008a, 2007-2008b).

\section{A beszédészlelési folyamat zavarai}

„A beszédészlelés és a beszédmegértés zavaráról akkor beszélünk, ha a müködés nem tökéletes”, vagyis ha „az elhangzott (a nyelv jelrendszerével megfogalmazott) üzenetek azonosítása nem pontos vagy azonosíthatatlan, a megértése bizonytalan akadályozott vagy lehetetlen, az értelmezése kérdéses, gátolt vagy lehetetlen; és mindennek felszíni megjelenése (tünete, tünetei) különféle (különfélék) lehet (lehetnek)" (Gósy, 1995 p. 7.).

A feldolgozó rendszer zavarára számos tünet hívhatja fel a figyelmet, például a kérdésekre adott nem adekvát válaszok, a hibás feladatmegoldás vagy bizonytalanság és az együttműködés hiánya. Gyakori a figyelmetlenség, viselkedési problémák megjelenése, a túlzott játékosság, vagy ennek ellenkezője, ha feltünően visszahúzódó a gyermek. A beszédészlelés zavarára utalhat a lassabb beszédfejlődés és az életkorától elmaradó szókincs. Továbbá a szavak torzítása is zavarra utaló tünet lehet (Gósy, 1995).

A beszédészlelés legalsó szintjének, az akusztikai szintnek a zavarai általában a felsőbb szintekre, vagyis a fonetikai és fonológiai szintekre is kifejtik hatásukat. Ha kizárólag az akusztikai szinten következik be zavar, akkor ez általában átmeneti, és egy idő után, amikor a hallás állapota rendeződik, meg is szünik. A fonetikai és fonológiai szintek zavara azonban tartósabb, így hatással lehetnek az artikulációra, a szókincsre, valamint a nyelvtani rendszerek, szabályok felismerésére. Ezek a zavarok magukkal vonhatják a szegényes beszédprodukciót, az olvasás- és írás zavarát, a helyesírás nehézségeit, az idegennyelv-tanulás problémáit és a memoriterek tanulásának nehézségeit (Gósy, 1995).

Imre (2007) vizsgálatában arra a következtetésre jutott tipikus fejlödésű 1-3. évfolyamos gyerekek esetében, hogy életkortól függetlenül, a beszédészlelés mindhárom szintjén elmaradás tapasztalható, mely leginkább a fonológiai szinteket érinti.

A beszédészlelés legsúlyosabb zavaráról akkor beszélünk, ha az egyes részfolyamatok csak részlegesen müködnek, vagy ha valamelyik egyáltalán nem müködik. Ebben az esetben a gyerekek szeriális és vizuális észlelése rendkívül gyenge, beszédhang-differenciálásra nem képesek, illetve nem érzékelik a beszéd ritmusát sem. Ennek következményei lehetnek beszédprodukciós zavarok, szük szókincs, nyelvi zavarok, súlyos olvasás- és írástanulási nehézségek, tanulási zavarok és a kognitív funkciók zavara (Gósy, 1995).

A szeriális észlelés lehetővé teszi, hogy a gyermek pontosan reprodukálja az elhangzott hangsorok sorrendjét. Hatéves korra már elvárható a hibátlan működése. (Bóna, 2007). A sorrendiség észlelése jelen van mind a fonetikai, mind pedig a fonológiai szintek müködésében, így az esetleges zavar is érinti mindkét szintet. Nehézség léphet fel az új 
szavak elsajátításában, a fonológiai szabályok alkalmazásában, az írott nyelv elsajátításában, a helyesírásban és a szó szerinti tanulásban (Gósy, 1995).

A vizuális észlelés elsősorban a fonetikai szint részfolyamata. Zavara esetén a gyermek nem tudja az ajakmozgásokat a beszédhangokkal azonosítani, amely a saját artikulációs mozgásainak fejlődését, ebből következően pedig a beszédészlelés alakulását is hátrányosan befolyásolja. Ennek következtében kialakulhat az izolált beszédhangok felismerésének nehézsége, a vizuális megerősítés hiánya, valamint a dekódolási folyamat mérsékelt müködése (Gósy, 1995).

A beszédhang-differenciálás a beszédészlelés folyamatának alapvető eredménye. Mind az azonosságok, mind pedig a különbözőségek azonosítása fontos része az anyanyelvelsajátításnak. A hatéves gyermek már képes megkülönböztetni anyanyelve beszédhangjait, az időtartambeli különbségek kivételével, mert ez utóbbiban még bizonytalanok, ám hétéves korra jellemzően ez is kialakul (Gósy, 1995).

Kutatások (Horváth és Gyarmathy, 2010) bizonyították, hogy a beszédhallás minősége összefügg a beszédhang-differenciálás képességével. Ha tehát gyenge ez a képesség, a gyermek képtelen az akusztikai kulcsok megfelelő azonosítására, így az egész beszédészlelési folyamat instabillá válik, amely akadályokat gördít az írott nyelv optimális elsajátítása elé, elörevetítve az iskolai kudarcokat. Az életkor növekedésével párhuzamosan azonban megjelennek bizonyos észlelést segítő kompenzációs technikák, amelyek azonban megnövekedett energiamennyiséget emésztenek fel.

A beszédmegértés során az elhangzott üzenet feldolgozása történik, mely tartalmazza a fonetikai, fonológiai, morfológiai, szintaktikai és szemantikai szabályok értelmezését. Két folyamatot különíthetünk el: a rövid közléseket és a szövegek feldolgozását, melyek dekódolásában más beszédértési szintek vesznek részt. A rövidebb egységek értelmezése során az alsóbb és felsőbb szintek részvétele párhuzamosan zajlik, azonban az asszociációs szint részvételére általában nincs szükség, míg a szövegértésnél elkerülhetetlen a folyamatba történő bevonódása, hiszen egyaránt szükséges a már meglévő ismeretek aktivizálása és a logikai összefüggések felderítése (Gósy, 1995). A korábbi pszicholingvisztikai elméletekkel szemben az újabbak a szövegértést aktív és konstruktív - az alkalmazott megértési stratégiák és tudássémák iránti érdeklődést kiváltó - mechanizmusok sorozataként írják le (Pléh és Lukács, 2014).

A mondatértés zavara az anyanyelv nyelvtani és szintaktikai rendszerének és szemantikai egységeinek hiányosságaira utal, így az ezzel a nehézséggel küzdő gyerekek nehezebben értik meg az elhangzott utasításokat, azok hiába rövidek és tömörek, így könnyedén mutatnak a tanulási zavarhoz hasonló tüneteket (Gósy, 1995).

A szövegértés zavara két módon következhet be, egyrészt a részletek megértése okozhat nehézséget, súlyosabb esetben pedig az összefüggések felismerése jelent problémát. A szövegértési zavar több következménnyel járhat, például a beszédprodukció, a kogníció, az olvasás értési nehézségeivel, tanulási problémákkal (Gósy, 1995). Az új nézetek (Pléh és Lukács, 2014) szerint a szövegfeldolgozás és értelmezés folyamatában a mondatokat nem egyesével értelmezzük, hanem egy, az emlékezetben megmaradó és teljes reprezentációt alkotunk a mondatok sorozatából.

Markó (2007) kutatása alapján megfogalmazta, hogy a 6-9 éves tipikus fejlődésü gyermekek mondatértése jobb a szövegértésüknél. Továbbá a mondatértésben tanúsított teljesítményük az életkor előrehaladtával globális szinten javulást mutat. Statisztikailag igazolta, hogy a mondat- és szövegértés közötti összefüggés igen gyenge, tehát szövegértés során a gyerekek alig támaszkodnak mondatértésükre, így arra következtethetünk, hogy más részképességeknek legalább olyan fontos szerepük van a szövegértésben, mint a mondatértésnek. 
A dekódolási folyamat két további fontos részfolyamata a verbális és a vizuális rövid idejü memória. A rövid idejü verbális memória zavara magával vonhatja a beszédhangok egymás után történő felidézésének pontatlanságát, a beszédhang-differenciálás és a szótagidőtartamok reprodukálásának nehézségét, míg a rövid idejü vizuális memória zavarának következménye lehet a betűazonosítás- és megtartás nehézsége, valamint a vizuális szerialitás problémája (Gósy, 1995).

Az agyfélteke-dominancia a beszédinger feldolgozása során alakul ki, ha azonban a gyermek nem tudja feldolgozni ezeket a beszédingereket, a kérgi dominancia kialakulása zavart szenved, melynek következtében az anyanyelv-elsajátítás és annak összes részfolyamatának fejlődése akadályozottá válik. A beszédpercepciós nehézséggel küzdő gyerekeknél így nagy arányban tapasztalható kialakulatlan lateralizáció (Gósy, 1995).

\section{AZ OLVASÁS}

Mivel az olvasás és írás képessége nem előhuzalozott az agyban, ezért az agy plaszticitását kihasználva olyan területeit hasznosítjuk erre a célra, amelyek alapvetően egy régebbi evolúciós mechanizmus részét képezik (Blomert és Csépe, 2012).

Az írás- és olvasástanulás képességének elsajátításához szükséges másik sajátosság a nélkülözhetetlen explicit tanulás, hiszen lényegében olyan önkényes asszociációkat, elemek egymással történő kapcsolatát kell megtanulnunk, amelyek csak az írás-olvasás kontextusában jelennek meg. A fonológiai dekódolás az alapja a folyékony, készségszintű olvasásnak, ez azonban az olvasástanulás kezdetén még rendkívül megterhelö folyamat. A cél azonban az, hogy az egyén a fonológiai dekódolásról áttérjen a teljes szó automatikus, vizuális mintafelismerésen alapuló azonosítására (Blomert és Csépe, 2012).

Nagy (2004) olvasásmodellje - amelyben a képesség számos hierarchikusan szerveződött összetevőből áll - pedagógiai szempontból kiemelkedő jelentőségü. Fazekasné (2006) két területre bontva gyüjti össze az olvasáshoz szükséges készségeket, képességeket: az akusztikus- és a vizuális észlelésre. Az akusztikus észlelés (beszédhanghallás) a beszédészlelés fonetikai, fonológiai szintje (Fazekasné, 2006). Segítségével válunk képessé a szóbeli közlések feldolgozására, valamint az artikulációs folyamatok szabályozására. A beszédhang-felismerés hibás müködéséért felelős lehet a nem megfelelő hallás, mely következtében az artikuláció szabályozása zavart szenvedhet. Hibátlan artikuláció esetén más, az olvasást nehezítő beszédhanghallási problémák is előfordulhatnak. A beszédhanghallás magában foglalja a beszédhang felismerését (fonológiai észlelés) és kiemelését (fonológiai tudatosság). Ez utóbbi folyamat biztosítja, hogy az egyén képessé váljon a szavakon belül előforduló beszédhangokkal történő müveletek végrehajtására (Nagy, 2006). E képesség kialakulása azonban az írás-olvasás tanulásához köthető, így csak ezek kezdete után jelenik meg. Implicit tanulással nem sajátítható el. (Blomert és Csépe, 2012).

Az olvasási készség vizuális elemei a betüfelismerő- és betükapcsoló, valamint a szófelismerő rutinok, továbbá a betü-, szó- és mondatolvasó készségek. Az olvasásban a vizuális percepció felel a betük felismerési és differenciálási gyorsaságáért (Fazekasné, 2006).

A betü felismerése a betüforma differenciálásával érhető el. A formaészlelés müveleteiben több összetevő vesz részt, hogy információkat szolgáltassanak a forma teljes rendszeréröl. A vizuális analízis és szintézis során az alakzat elemire bontása történik meg. Az alak-háttér differenciálás során a látás fókusza befolyásolja, hogy melyik részletet emeli ki a háttérből, így a figyelem középpontjába is az az alakzat kerül. Zavara figyelmetlenségnek hathat, ám valójában ingerhez tapadásról van szó. Az alakkonstancia a formák/betűk állandó tulajdonságainak felismeréséért felelős, míg a téri helyzet és térbeli viszonyok az egymáshoz viszonyított elrendezést helyezik előtérbe. Az arányészlelés, vagyis a méretbeli eltérések 
pontos észlelése a betűdifferenciálás fontos részét képezi (Gerebenné, 1994 id. Fazekasné, 2006 p. 201.).

Az olvasás- és írástanulás első és legfontosabb lépése a betüismeret, vagyis a hang-betü megfeleltetések elsajátítása, melyek a későbbi folyékony olvasás alapját képezik. A legújabb kutatási adatok azt igazolják, hogy a betủ és hang dekódolásának teljes automatizálása évekig is eltarthat és a tanulási problémákkal küzdők ezeket az asszociációkat később sem tudják megfelelöen feldolgozni (Blomert és Csépe, 2012).

A gyors automatikus megnevezés (RAN - rapid automatized naming) a harmadik, olvasáskészséghez kapcsolódó kognitív faktor. Ennek feladata a mindennapokban gyakran megjelenő vizuális elemek (betük, számok, tárgyak, színek) gyors és egyben automatikus megnevezése. Míg a fonológiai tudatosság az álszavak olvasásával hozható összefüggésbe, addig a RAN teljesítményét a vizuális szófelismerés befolyásolja (Blomert és Csépe, 2012).

\section{A BESZÉDÉSZLELÉS ÉS AZ OLVASÁS KAPCSOLATA}

Gósy és Horváth (2007) óvodás és olvasási nehézséggel küzdő gyerekek beszédhallás és beszédészlelés folyamatait vizsgálta. Kutatásuk alátámasztotta azt a feltevést, hogy az életkorral a fonetikai és fonológiai észlelés kismértékü minőségi javulása várható, ugyanakkor nagy egyéni különbségek voltak jellemzők mindkét csoportban, amelyek az életkor előrehaladtával sem csökkentek. A fonetikai észlelés mindkét korcsoportban meghaladta a fonológiai észlelés szintjét. Továbbá arra a következtetésre jutottak, hogy az iskolai tevékenységek és az életkori fejlődés - célzott fejlesztés hiányában - nem elég a jól müködő beszédfeldolgozáshoz. Az olvasási nehézségek oka tehát a résztvevő folyamatok elmaradott müködése, illetve ezek egymástól való függése.

A beszédészlelés és olvasás egymást erősítő kapcsolatát támasztja alá az a tény is, hogy az olvasni tanuló gyermek jobban megérti a szöveget, ha hangosan kiejtheti a szavakat, továbbá az artikulációval kísért írás, helyesírás is jobb. Ez utóbbi bizonyítja az észlelés motoros müködését is (Adamikné, 1996).

Számos kutatás (Kraus és tsai, 1999; Baran, 2002 idézi: Putter-Katz és tsai, 2005 p. 215.; Chiappe és tsai, 2001; Gráczi, 2007) foglalkozott már a tanulási problémával küzdő személyek között nagy arányban előforduló beszédpercepciós hátrányokkal. Putter-Katz és munkatársai (2005) kutatásukban ép értelmü, tanulási problémával küzdő fiatalok auditívfonetikai és auditív-nyelvi folyamatainak müködését vizsgálták olvasási nehézségek megléte és hiánya esetén. A kutatók célja volt az olvasási, nyelvi és munkamemóriával kapcsolatos készségeik, képességeik, illetve a zajjal fedett álszavak észlelési hatékonyságának mérése. Az eredményekből arra a következtetésre jutottak, hogy az olvasási problémájával küzdő személyek fonológiai és nyelvi elmaradásai nem a háttérzajokra való megnövekedett érzékenységük miatt kialakult zavart beszédészlelési folyamatok müködéséből eredeztethetők.

Chiappe (és tsai, 2001) a beszédpercepció és a lexikális információ kapcsolatát vizsgálta gyengén és jól olvasó, 7 éves, ép értelmü gyermekek körében az olvasás, a fonológiai tudatosság, álszavak ismétlése és fonémaazonosítás mérésének segítségével. A gyengén olvasó gyerekekre jellemző volt a fonémaazonosítás nehézsége, melyből arra következtettek, hogy a kategoriális észlelésük kevésbé meghatározott a jól olvasókhoz képest. Az eredmények azt feltételezik, hogy a zavart beszédészlelésnek valószínüleg nagy befolyása van a fonológiai tudatosság alakulásában, amely pedig az olvasási nehézségért tehető felelőssé. Mindezeken túl még úgy találták, hogy a mentális lexikon is nagy hatással van a beszédészlelés fejlődésére mindkét gyermekcsoportban.

A fonémaazonosítással kapcsolatban Snellings és munkatársai (2010) azt találták, hogy az olvasási zavarral küzdő 7 éves gyerekek lassabban, de ugyanolyan arányban ismerik fel 
ugyanazokat a hangokat, így kevésbé különítik el a fonémakategóriákat egymástól, vagyis a fonémareprezentációkhoz történő automatikus hozzáférés szenved zavart.

\section{TANULÁSBAN AKADÁLYOZOTTSÁG ÉS A BESZÉDÉSZLELÉSI-, BESZÉDMEGÉRTÉSI FOLYAMATOK}

A tanulásban akadályozottság a tanulás minden területén jelentkezik tartós és átfogó nehézségeket okozva. Jellemző a kognitív funkciók és a beszéd lassabb ütemü fejlödése, valamint a koncentrációban és a viselkedésben megmutatkozó szociális képességzavarok. Elöidézhetik hátrányos szociális környezeti hatások, valamint kisebb mértékü központi idegrendszeri sérülés, amely enyhe fokban sérült értelmi képességet eredményezhet. Mesterházi (1998) meghatározása szerint „,a tanulásban akadályozottak csoportjába tartoznak azok a gyermekek, akik az idegrendszer biológiai és/vagy genetikai okokra visszavezethető gyengébb funkcióképességek, illetve a kedvezőtlen környezeti hatások folytán tartós, átfogó tanulási nehézségeket, tanulási képességzavart mutatnak.” (Mesterházi, 1998, p. 54.).

A tanulásban akadályozott gyerekek beszédészlelési és beszédmegértési folyamatai várhatóan a tipikusan fejlődő gyermekek átlagteljesítményét minőségileg nem érik el, hiszen a mentális érintettség hatással van a nyelvhasználatra, és a nyelvhasználat is befolyással bír a mentális folyamatokra (Gósy, 2007b). Így az kognitív deficit magával vonhatja a késői beszédindulást és a lassabb beszédfejlődést (Torda, 1995 id. Gósy, 2007b p. 231.), valamint a beszédjükre jellemzők lehetnek különféle artikulációs eltérések, vagy más beszédprodukciós zavarok, továbbá beszédészlelési- és megértési nehézségek. Ugyanakkor az analizálószintetizáló folyamatokban is zavarok léphetnek fel, amely az olvasás- és írástanulást is megnehezíti. Ezáltal a szókincsük bővítése is gátolttá válik és a kommunikációs nehézségek miatt a mentális érintettség is súlyosbodhat (Gósy, 2007b).

Gósy (2007b) kutatásában arra kereste a választ, hogy a tanulásban akadályozott gyermekek közül milyen a határeseti intellektusú és az enyhe fokban értelmi fogyatékos gyerekek beszédpercepciós mechanizmusa egymáshoz, és tipikus fejlődésü gyermekekhez mérten. Az eredmények megerősítették, hogy az intelligenciaszint a beszédmegértés folyamatát nagyobb mértékben befolyásolja, mint az észlelési müködéseket, hiszen az enyhe fokban értelmi fogyatékos gyerekek beszédészlelésének átlaga 57,60\%, míg beszédértésük átlaga 34,08\%. Azonban ez a megállapítás csak csoportszinten állja meg a helyét, hiszen az egyéni különbségek olyan nagyok, hogy ez az összefüggés már nem feltétlenül érvényesül egy-egy gyermek esetében (Gósy, 2007b).

Macher $(2007,2012)$ ép beszédprodukciójú, 7 és 10 éves, integrált körülmények között tanuló tanulásban akadályozott gyerekek beszédészlelési és beszédmegértési teljesítményét mérte. Arra a következtetésre jutott, hogy a 10 éves gyermekek 34\%-a küzd beszédészlelési zavarral, 66\%-nál elmaradás tapasztalható, míg a 7 évesek 56\%-ánál áll fenn zavar. A szeriális észlelés is, mindkét életkori csoportban a 3 évesek átlagának, vagy az alatti teljesítménynek felel meg, ami rendkívül nehezítetté teszi többek között a problémamentes írás- és olvasástanulást. A 7 évesek transzformációs észlelésének vizsgálata során már a feladat megértésének problémájába ütköztek, ám 10 éves korban is kimutatható a 3 évvel történő elmaradás, így ez a részfolyamat is, a többihez hasonlóan, a legsúlyosabb kategóriába esik. Továbbá a szövegértés súlyos elmaradása is egyértelműen megmutatkozik, a 7 éves kortól elvárható $100 \%$-os teljesítményt egyik 10 éves gyermek sem érte el. A 7 éves gyerekeknél jellemzőbb a válaszok elmaradása, míg idősebb társaik sajátsága inkább az inadekvát válaszok adása. A mondatértés is 7 évesen mérsékelten, míg 10 évesen súlyos elmaradást mutat, ám nincs olyan nagy szórás az egyéni eredmények között. A legnagyobb problémát az időviszonyok, a részeshatározós szerkezet és a szokatlan szórendű tagadás értelmezése okozta. A 7 évesekre jellemzőbb volt a visszakérdezés és a bizonytalanság, míg a 
10 éveseknél ezzel ellentétben a megfontoltság hiánya volt megfigyelhető (Macher, 2007, 2012).

A tanulásban akadályozott gyerekek gyakran nehézségekbe ütköznek az olvasástanulás folyamata során. Nemzetközi szakirodalom (Koritsas és Iacono, 2011 In: Channell és tsai, 2013) szerint az olvasási gondok az egyik leggyakoribb másodlagos problémája az értelmi fogyatékosságnak. A másodlagos problémákat, tüneteket megelőzhetőnek tartják, így elviekben megfelelő módszerekkel az olvasási nehézségek kiküszöbölhetővé válhatnának a tanulásban akadályozott gyerekek számára. Jelenleg azonban csak annyit tudunk, hogy az enyhén értelmi fogyatékos gyerekek nagy nehézségek árán tudnak megtanulni olvasni. A jövőbeni kutatásoknak arra kellene összpontosítania, hogy hogyan megy végbe ez a folyamat, és csak akkor tudjuk megtenni a szükséges lépéseket a megfelelő módszerek, programok kidolgozására (Channell és tsai, 2013).

A magyar nyelv írott rendszerének elsajátításához számos olyan készség, képesség birtokában kell lenni, amelyek hiányában az olvasás- és írástanulás nehezítetté, akadályozottá válhat. Ilyen feltétel a beszédhanghallás, a hanganalízis, a vizuális differenciálás megfelelő fejlettsége, mely szoros kapcsolatban áll a térbeli tájékozódással, továbbá a jelfunkció megléte, a szókincs és a tiszta hangképzés. A tanulásban akadályozott, enyhén értelmi fogyatékos gyermekek pont ezeknek a területeknek a kialakulatlanságával, elmaradásaival kezdik meg az iskolát. Így a gyógypedagógusokra hárul a feladat, hogy a klasszikus olvasástanulási módszerekkel ellentétben sokkal nagyobb hangsúlyt fektessenek az alapkészségek- és képességek fejlesztésére, hogy az olvasástanulás elkezdésekor a kezdőszinthez szükséges tudás a kezükben legyen (Papp, 2011).

Channell és munkatársai (2013) az olvasáshoz szükséges képességeket hasonlították össze enyhén értelmi fogyatékos és a biológiai életkor alapján fiatalabb, tipikus fejlődésű, de hasonló verbális szinten lévő gyermekeknél. Céljuk az volt, hogy azonosítsák az olvasáshoz szükséges képességek közül azokat, amelyek a tanulásban akadályozott gyerekek erősségeit, illetve gyengeségeit képezik. Az eredmények azt mutatták, hogy a tanulásban akadályozott gyerekek általános szófelismerési képessége gyengébb, mint a tipikus fejlődésűeké. A helyesírási folyamatok és a gyors automatizált megnevezés (RAN) tesztekben nem találtak szignifikáns különbséget a két csoport között, ezzel ellentétben az enyhén értelmi fogyatékos gyerekek fonológiai dekódolásának (mind a fonológiai tudatosság és memória) minősége nagymértékben elmarad tipikus fejlődésű társaikétól. A kutatás tehát felhívja a figyelmet arra, hogy az elmaradott fonológiai dekódolás képessége nagyban hozzájárul a szófelismerési képesség fejlődéséhez, azonban a relatíve jól müködő helyesírási és gyors automatizált megnevezési képességeiket nem használják ki megfelelő mértékben a fejlődés érdekében.

Az olvasási készség fejlődéséről különböző adatok szólnak. Szalayné (1976 id. Papp, 2011 p. 14.) megállapította, hogy a megértés 3. és 8. évfolyam között eredményesebben fejlődik, mint a tempó, és gyakorta jobban is értik a gyerekek a szöveget, mint azt az olvasástechnikájuk indokolná (Papp, 2011).

A szegregáltan oktatott, tanulásban akadályozott gyerekek szövegértése minden életkorban szignifikánsan elmarad tipikus fejlödésü társaiktól, azonban a különbség az életkor elörehaladtával csökken (Papp, 2011). A tanulásban akadályozott diákok szövegértése legalább négy évvel elmarad a többségi társakéhoz képest (Józsa és tsai, 2014).

$\mathrm{Az}$ integráltan oktatott, gyógypedagógusi segítséget kapott tanulásban akadályozott gyermekek szövegértési képessége jelentősen jobb, közelebb esik a többségi gyerekek teljesítményéhez, mint szegregáltan oktatott társaikéhoz (Papp, 2011; Józsa és tsai, 2014).

A szóolvasás képességének fejlődése tipikusan fejlődő gyermekek esetében harmadik osztályos korra befejeződik, a tanulásban akadályozott gyermekek esetében azonban némi fejlődése még tapasztalható a 7. évfolyamig (Papp, 2011; Józsa és tsai, 2014). A két csoport 
közti szignifikáns különbség az életkor elörehaladtával továbbra is fennmarad (Papp, 2011). A szövegértés fejlődése jelentős a 3. és 7. évfolyam között is (Józsa és tsai, 2014).

\section{A KUTATÁS CÉLJAI ÉS HIPOTÉZISEI}

A tanulási akadályozottság elsősorban a tanulási/iskolai helyzetekben előforduló probléma, amely magában foglalja többek között a kogníció és a kommunikáció eltérő fejlődését, mely természetes módon hatással van az észlelésre, a dekódolásra és a kivitelezésre is. Igy az anyanyelv elsajátításában és használatában különböző fokú eltéréseket tapasztalhatunk mind a hallott beszéd feldolgozása és az írott nyelv feldolgozása, azaz az olvasás területén.

A kutatás célja, hogy feltárja a 3. és 4 . évfolyamos tanulásban akadályozott és tipikusan fejlődő gyermekek beszédfeldolgozási, valamint olvasási képességeit, különösen figyelve a típushibák és a folyamatok között megjelenő összefüggésekre, a következő főbb hipotézisekre keresve a választ:

1. Az integráltan oktatott tanulásban akadályozott gyermekek vizsgálati eredményei (Macher, 2013) alapján feltételezhető, hogy a szegregáltan oktatott tanulásban akadályozott gyermekek mindkét évfolyamon súlyos elmaradásokat mutatnak a beszédfeldolgozás minden vizsgált szintjén. Az észlelés területén valószínüleg a fonológiai szint müködése a leggyengébb, illetve a szövegértés gyengébb müködése tapasztalható a mondatértés szintjéhez képest. Az észlelés komponenseinek müködése között különböző erősségü összefüggés feltételezhetö.

2. A tapasztalat és empirikus eredmények (Papp, 2010; Józsa és tsai, 2014) alapján valószínüsíthető, hogy a tanulásban akadályozott gyermekek olvasási készsége jelentős eltérést mutat a tipikusan fejlődő gyermekek teljesítményéhez képest. A betü-, szótag-, szó- és szövegolvasás minősége között feltehetőleg szoros összefüggés tapasztalható.

3. A beszédfeldolgozás gyenge minősége az olvasás nehezített elsajátításához vezet (Adamikné, 1996). Feltételezhető, hogy a súlyos beszédpercepciós elmaradás az olvasás minőségében és a szövegértésben is jelentős nehézséget jelent. A kutatási eredmények alapján (Gósy, 1995; Csépe, 2007) feltételezhetö, hogy a beszédpercepciós és az olvasási képességek minősége között szoros összefüggés mérhető. Hasonló hibatípusok előfordulása valószínüsíthető a hallott és olvasott információk feldolgozása esetében.

\section{MÓDSZER}

\section{Minta}

A kutatásban összesen 51 fö vett részt. Mindannyian 3-4. évfolyamos tanuló. A célcsoport 26 fő tanulásban akadályozott gyermekből állt, közülük 13 fő 3 ., és 13 fő 4 . évfolyamos. Mindegyikük ép hallású, és Északnyugat-Magyarország szegregált általános iskoláiba járnak, átlagéletkoruk 10;3 év.

A kontrollcsoport tagjai közül 13 fö 3. osztályos, 12 fö 4. osztályba jár. Mindannyian átlagosan teljesítenek az iskolában, illetve ép intellektusúak, a tanulásban akadályozott gyermekekével azonos településen élnek, átlagéletkoruk 9;8 év.

\section{Eszközök}

A beszédészlelés és beszédmegértés folyamatának vizsgálatára a GMP-diagnosztika eljárását alkalmaztuk. A sztenderdizált eljárás lehetővé teszi, hogy a részfolyamatokat a teljes mechanizmustól elkülönítve, külön-külön is megvizsgáljuk, illetve, hogy az egyes fejlödési szintek elmaradását vagy zavarát is elhatárolhassuk a megfelelően müködő szintektől. (Gósy, 2006). 
A rendelkezésre álló altesztek közül a beszédészlelés szintjeinek müködését vizsgáló részteszteket alkalmaztuk: az akusztikai észlelésröl a GMP2, amely zajban történő mondatazonosítás, illetve a GMP3, ami szóazonosítás zajban adnak képet. A fonetikai észlelést a szük frekvenciás mondatok mérik a GMP4-gyel, míg a GMP5 a fonológiai észlelés müködését vizsgálja mesterségesen felgyorsított mondatok azonosításával. A GMP10 a beszédészleléshez szükséges egyik részfolyamatot méri, az értelmetlen hangsorok azonosításával történő szeriális észlelést. A beszédmegértést vizsgáló teszteket is elvégeztük a gyerekekkel, így a szövegértés (GMP12) és a mondatértés vizsgálatát is (GMP16). A sztenderd eredmény 7 éves kortól $100 \%$ minden elvégzett altesztben.

Az olvasás vizsgálatára Meixner Ildikó olvasólapokat dolgozott ki, melyekben törekedett a fokozatosságra, így a betüolvasást (magán-, majd mássalhangzók) követi a szótag, a szó és végül a szöveg olvasása. Minden részfeladatban azonos egységü (50 db) elem található, így könnyen összevethetö, hogy mely szinten milyen tempóval olvas, és milyen mennyiségi és minőségi hibákat ejt a tanuló (Meixner, 1995; Sipos, 2017).

A vizsgálólap összeállításánál különös figyelmet szentelt a homogén gátlás általános törvényszerüségeire, mely szerint a tanulók nehezebben vésik be a hasonló elemeket tartalmazó anyagokat, legyen ez akár betü, szó, vagy témakör. Így megnövekszik a felejtés valószínüsége, a reakcióidő meghosszabbodik, nő a hibák száma és a tanulási folyamatot bizonytalanság kíséri. Az olvasás területén a betük vizuális és fonetikai hasonlóságának van nagy jelentősége. A homogén gátlás jelenségét tehát direkt módon építette be az olvasólap feladataiba, hogy minél több hiba és bizonytalanság kiderüljön. (Meixner, 1995; Sipos, 2017).

A kutatáshoz a 3-4. évfolyamos tanulók számára összeállított, nemrégiben sztenderdizált olvasólapot használtuk, amelyeket a Pedagógiai Szakszolgálatok országszerte alkalmaznak. Az országos kutatás eredményei alapján a gyermekek átlagideje $248 \mathrm{mp}, 20$ olvasástechnikai hiba és 2 értési hiba, így a megállapítások szerint akkor olvas gyengén a gyermek, ha $320 \mathrm{mp}-$ nél hosszabb ideig olvas, 19-nél több olvasási, valamint 3, vagy annál több értési hibát ejt. Az előző olvasólappal ellentétben az olvasás során ejtett, de javított tévesztéseket is hibának kell számolni (Meixner Alapítvány, 2016; Sipos, 2017).

\section{Eljárás}

A tipikusan fejlődő és a tanulásban akadályozott gyermekek minden szempontból egyező vizsgálatban vettek részt, a mérés körülményei azonosak voltak. A beszédészlelési vizsgálatokhoz szükséges hanganyagokat számítógép segítségével játszottuk le. A tesztek elvégzésére minden esetben egyénileg került sor, a feladatok sorrendjének megváltoztatását a vizsgálati protokoll lehetővé teszi, egy gyermek esetében indokolt volt élni a lehetőséggel. A gyerekek a vizsgálat során pozitív visszajelzéseket kaptak. Az adatok kiértékelése az SPSS 20.0 statisztikai programmal történt.

\section{Eredmények a beszédfeldolgozásban}

A GMP teszt eredményeinek feldolgozása három fő szempont alapján történt. Elsőként az észlelés eredményeit, majd az észlelési részfolyamatokhoz tartozó szerialitást, végül pedig a megértés területének adatait ismertetjük.

$\mathrm{Az}$ összes elvégzett alteszt átlageredményét szemlélteti az 1. ábra. A tanulásban akadályozott tanulók összesített átlaga 67,5\%, míg a kontrollcsoporté 82,3\%. Az ábrán látható, hogy a beszédészlelés összesített eredménye (PQ) és a megértés összesített eredménye (MQ) alig mutat eltérést az összes elvégzett alteszt átlageredményével. A két vizsgált csoport eredményei jelentős eltérésre utalnak, a statisztikai vizsgálat a beszédészlelés 
és -megértés minden altesztjében szignifikáns eltérést mutat a cél- és kontrollcsoport teljesítményei alapján.

1. ábra. A célcsoport és a kontrollcsoport összesitett átlageredményei

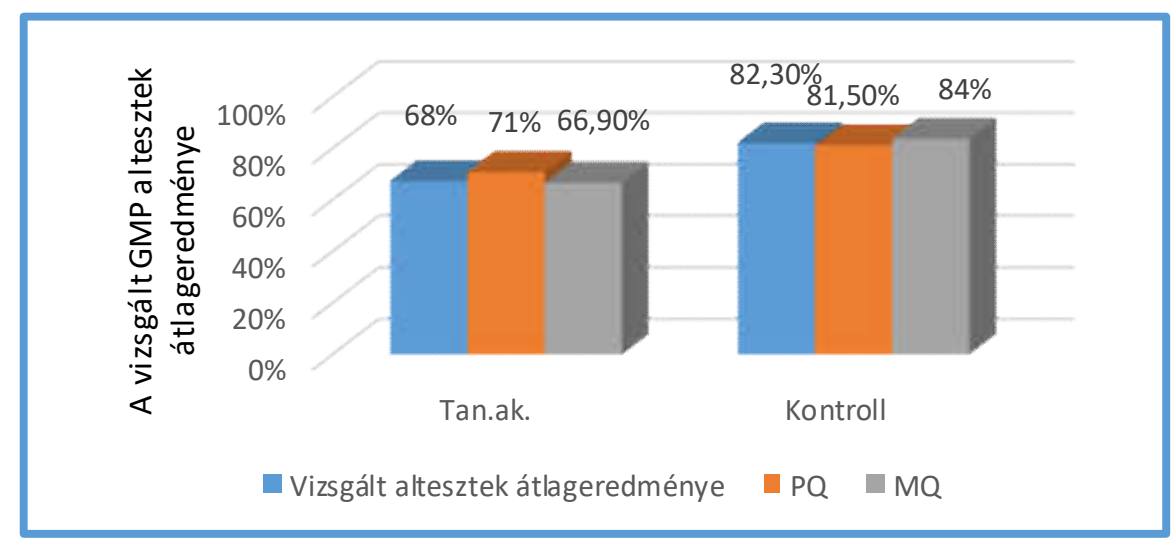

A beszédészlelés eredményeit részletezve (2. ábra): az akusztikai észlelést mérő tesztek, a GMP2 és GMP3 átlageredménye a tanulásban akadályozottak esetében 77,38\%, míg a kontrollcsoporté $81,5 \%$. A mondatismétlés során a gyermekek mintegy fele rosszul ismételte meg a legelső mondatot: A sütemény nagyon finom volt., míg a szóismétlésben a meggy és a szita szavak ismétlési hibái voltak a leggyakoribbak.

A fonetikai észlelést a GMP4-ben hallható szűk frekvenciás mondatokkal mértük. A tanulásban akadályozott tanulók átlagteljesítménye 83,5\%, a kontrollcsoporté 90,8\%. Ebben a résztesztben a gyermekek mindkét vizsgált csoportban változatos hibákat mutattak.

Az észlelést vizsgáló tesztek közül valamennyi csoportban a GMP5, vagyis a fonológiai észlelést mérő teszt eredményei a legalacsonyabbak. A célcsoport összteljesítménye 45,25\%, a kontrollcsoporté $68 \%$. A gyorsított mondatok esetében több olyan elem is volt, amely általánosságban nagyobb problémát okozott a gyerekeknek, így a leggyakoribb téves ismétlések között szerepelt a Ne gyártsatok selejtet! és az Átkokat szórt mások fejére mondat.

2. ábra. Az észlelés szintjeinek átlageredményei

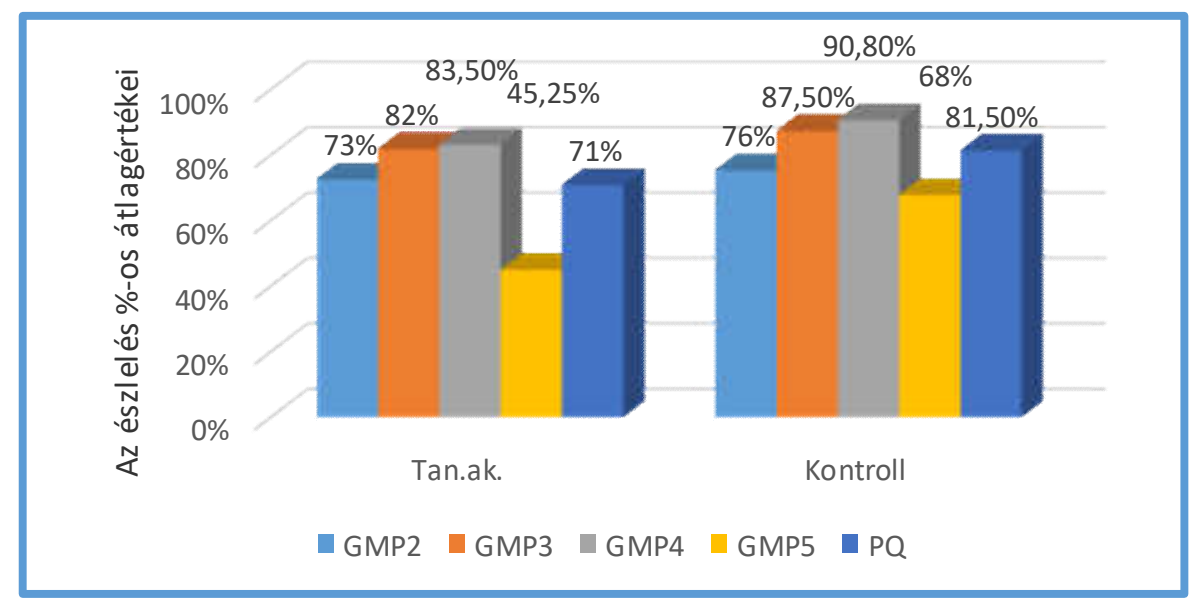


$\mathrm{Az}$ észlelési teljesítmény alapján felrajzolhatjuk a percepciós küszöbgörbét, mely szemléletesen megmutatja a vizsgált személy észlelési teljesítményét. Gósy (2000) és Horváth (2007) határozták meg a 9 leggyakoribb görbetípust és azok altípusait, melyek jelezhetik az elmaradást, vagy a zavart. A kettő közötti különbséget az határozza meg, hogy a görbe követie az életkor fejlödési vonulatát. A tipikus, életkor szerinti fejlödés azt feltételezi, hogy az észlelés akusztikai szintjén belül a szóazonosítás magasabb szinten müködik, mint a mondatazonosítás. Ha ez teljesül, de az életkor alapján elvárható szint alatti értéket éri el a gyermek, elmaradásról beszélünk. Amennyiben a görbe nem követi az életkor fejlödési vonulatát és a szavak észlelése gyengébben müködik, mint a mondatészlelés, már zavarról beszélünk. A célcsoport esetében 5 fönél jelenik meg ilyen típusú zavar, a kontrollcsoportban 3 fönél tapasztalható ez az eltérés. A többi gyermek eredménye elmaradásra utal.

A gyermekek eredményei alapján kirajzolódó valamennyi percepciós görbe megtalálható a fenti 9 fö típus között, például: a háztetö, forditott teknö, csökkenö, hegyvonulat és fürészfog típusú görbék. Az átlageredmények alapján a percepciós görbe különböző vonulatait tapasztalhatjuk a két csoportnál. A tanulásban akadályozottak percepciós átlagát tekintve a fordított teknő típusú észlelési elmaradás tapasztalható, a kontrollcsoportnál pedig a hegyvonulat zavartípus rajzolódik ki (3. ábra).

\section{3. ábra. A célcsoport és kontrollcsoport percepciós görbéje}

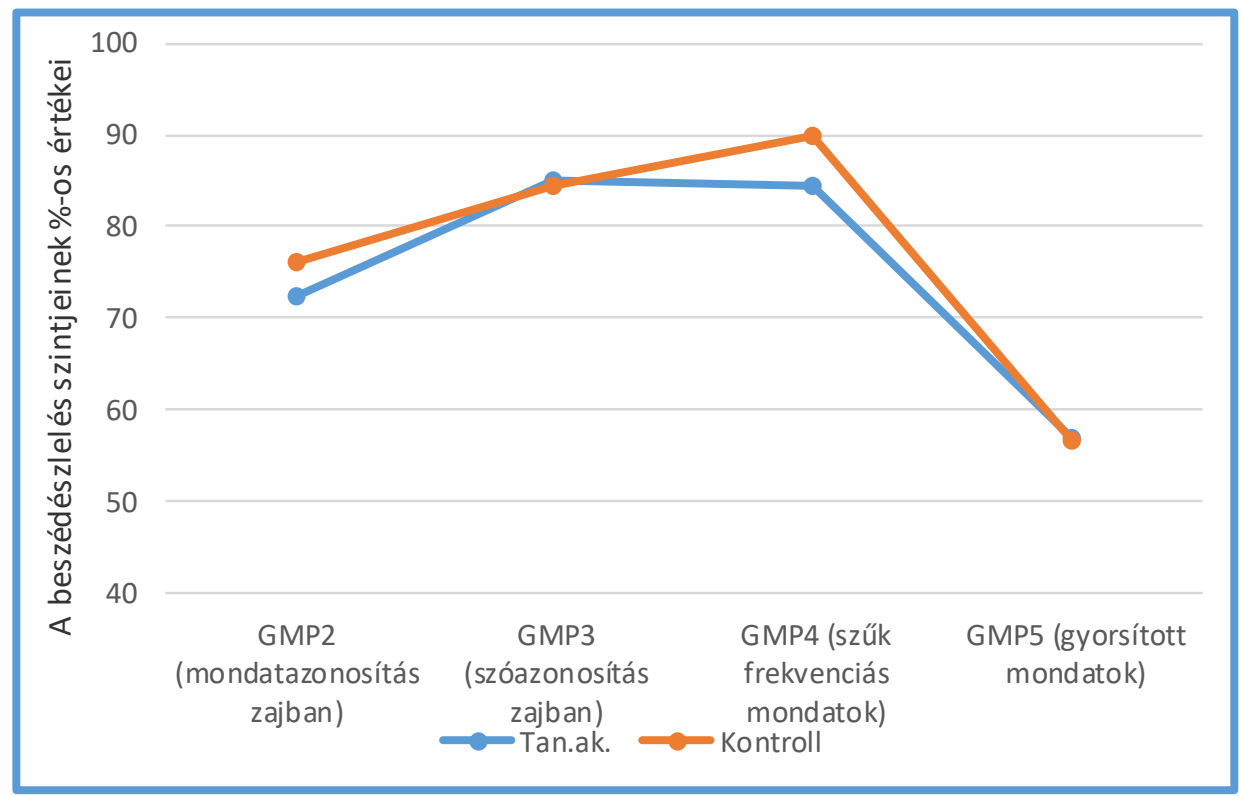

Az észlelési részfolyamatok közül a szeriális észlelést a GMP10 altesztet vizsgálta. A tanulásban akadályozottak átlageredménye 53\%, a kontrollcsoporté 87,5\%. A leggyakoribb hibák elöfordulása mindkét csoportot érinti, a vucsityó és kriszposztyüvan álszavak észlelése jelentette a legnagyobb problémát.

A beszédfeldolgozás harmadik szintje a beszédmegértés, ezen belül a mondat- és a szövegértést vizsgáltuk. A 4. ábra mutatja be a mondat- és a szövegértés átlagértékeit.

A mondatértés tekintetében a csoportok közel azonos szinten teljesítettek: a tanulásban akadályozottak 89\%-os, a kontrollcsoport pedig 92,75\%-os átlaggal. A szövegértésben 
azonban már több eltérés tapasztalható: a tanulásban akadályozott tanulók átlagosan 46\%-os eredményt értek el, a kontroll gyerekek pedig 75\%-ot. A tanulásban akadályozottak mintegy felének (50\%), míg a kontrollcsoport közel negyedének (24\%) okozott nehézséget a Mielött a maci ivott, evett egy kicsit mondat ritka időrendjének megértése.

A szövegértést mérő tesztben több kérdés is gondot okozott a gyerekek számára. Amíg a Mit szóltak az állatok ahhoz, amit Teknöc mondott? kérdésre a tanulásban akadályozottak 81\%-a rosszul, vagy egyáltalán nem válaszolt, addig a kontrollcsoport tagjainak 48\%-ának okozott nehézséget helyesen megválaszolni. Ugyanilyen problémás volt az utolsó, összefüggést vizsgáló kérdés Miért nyerte meg a versenyt Teknőc? A válaszban a tanulásban akadályozottak 81\%-a, míg a kontroll csoportba tartozó gyerekek 44\%-a adott helytelen választ, mely többségében a cselekedetre Mert csalt/ átverte a többieket. és nem Teknőc tulajdonságára, személyiségjegyére Mert ravasz volt. helyezte a hangsúlyt.

\section{4. ábra - A megértés átlageredményei}

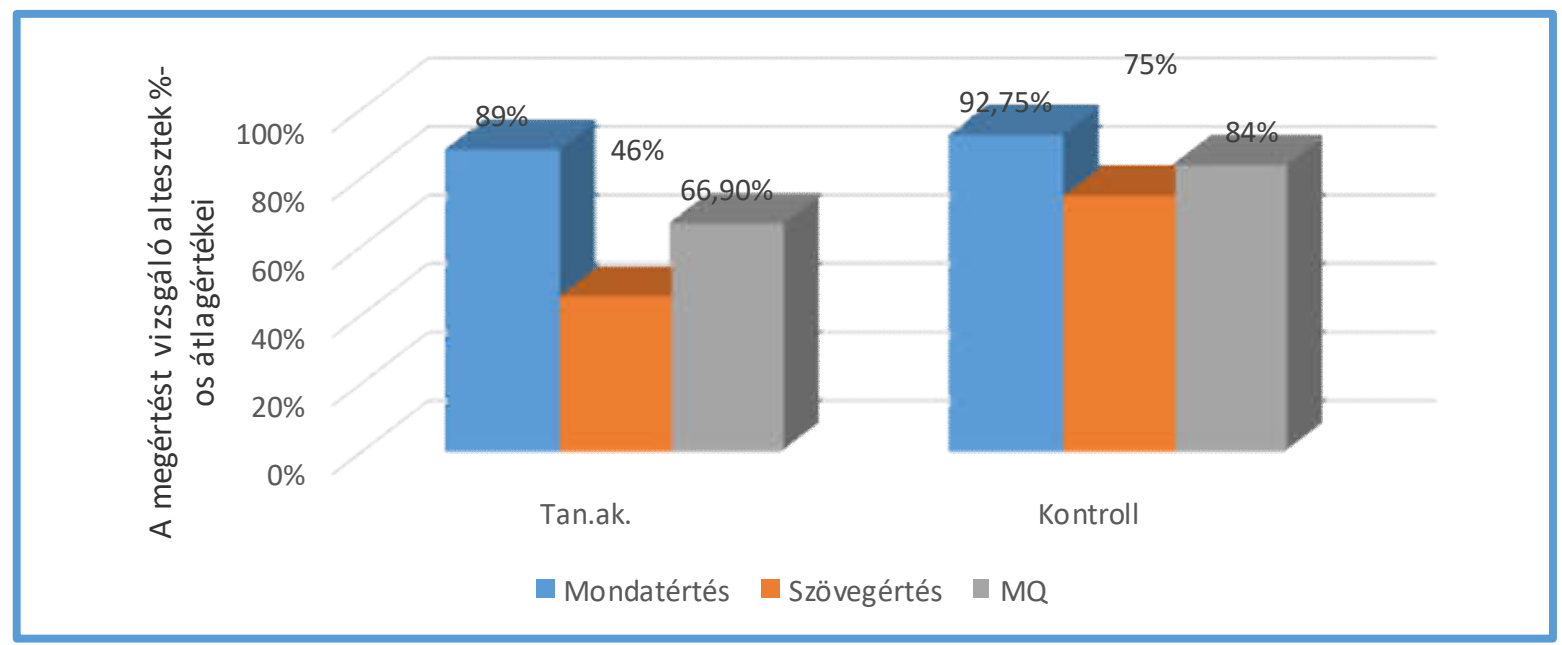

A beszédfeldolgozás komponenseit vizsgálva a tipikus fejlődésű gyermekek esetében a Pearson-féle korrelációanalízis összesen négy összefüggést igazolt. Gyenge kapcsolatot eredményezett a fonetikai és fonológiai észlelés $(r=.401)$, a fonetikai észlelés és mondatértés $(r=.46)$, illetve a fonológiai észlelés és mondatértés $(r=.446)$ között 95\%-os szignifikanciaszinten. Közepesen erős kapcsolatot a fonológiai észlelés és szövegértés minősége mutatott ( $r=.587$ ) 99\%-os szignifikanciaszinten. A tanulásban akadályozott tanulók esetében a komponensek több, és jellemzően erősebb összefüggést mutatnak a Pearson-féle korrelációanalízis alapján. Az akusztikai észlelés erős összefüggést mutat a fonetikai észleléssel $(r=.803)$, közepesen erős összefüggést a fonológiai $(r=.612)$ és szeriális észleléssel $(r=.583) 99 \%$-os szignifikanciaszinten. A fonetikai észlelés közepesen erős összefüggést mutat a fonológiai ( $r=.552)$ és szeriális észleléssel $(r=.680) 99 \%$-os szignifikanciaszinten. A fonológiai észlelés gyenge kapcsolatot mutat a mondatértéssel $(r=.339)$ és a szeriális észleléssel $(r=.481)$ 95\%-os szignifikanciaszinten. 


\section{Az olvasásvizsgálat eredményei}

Megállapítható, hogy a teszt sztenderd értékei alapján valamennyi csoportban vannak gyengén olvasó gyerekek. A gyengén olvasó gyerekek aránya a tanulásban akadályozottak körében magasabb. Ök föleg a meghatározott hibaszámot lépik túl, míg a kontrollcsoportban inkább az értő olvasás problémája a gyakoribb. Összességében véve a tanulásban akadályozott gyerekek 85\%-a olvas gyengén, s egyedül náluk található példa mindhárom terület (tempó, hibaszám, értés) együttes elmaradására, míg a kontrollcsoport 50\%-át érinti a gyenge olvasás problémája.

A cél és kontrollcsoport eredményei alapján a statisztikai vizsgálat az olvasás idejét, a hibaszámokat és a szövegértést tekintve is szignifikáns eltérést mutat.

Az olvasólap adatainak feldolgozása során összesítettük az olvasási tempót, a hibákat mennyiségileg és minőségileg egyaránt, illetve a javított hibák arányát. Az olvasási tempó összesített átlaga az egész olvasólap tekintetében a tanulásban akadályozottak körében 334 mp, míg a kontrollcsoportnál $243 \mathrm{mp}$. Amennyiben az olvasástechnikai szintek olvasási tempóját külön vizsgáljuk, megállapítható, hogy a gyerekek többnyire a betük szintjén olvastak a leggyorsabban, a szótagok olvasása közepes tempóval történik, leglassabban pedig kivétel nélkül, mind a két csoportnál azonos eredmény született: a szavak olvasására fordították a legtöbb időt.

Az olvasólapon ejtett hibák spontán javítását tekintve a kontrollcsoport átlagosan jobban teljesített a tanulásban akadályozott gyerekeknél, és ők törekedtek leginkább a korrigálásra is, átlagosan a hibáik 34\%-át javították. A tanulásban akadályozottak átlagosan több hibát ejtettek a kontrollcsoportnál, és ezeknek csupán 15,5\%-át javították ki. A hibázások átlaga másképpen alakul a különbözö olvasástechnikai szinteken.

A magánhangzók olvasásakor a tanulásban akadályozottak olvasási tempója átlagosan 49 mp, míg a kontrollcsoporté 41,5 mp. Az átlaghibák a célcsoport esetében 3,15 db, melynek mintegy $21,5 \%$-át javították. A kontrollcsoport tagjai átlagosan két hibát ejtettek, és ezek felét korrigálták is.

A mássalhangzók esetében is hasonló eredmények születtek. A tanulásban akadályozottak olvasási átlagtempója 47,8 mp, a kontrollcsoporté pedig ezen az olvasástechnikai szinten is 41,5 mp. A tanulásban akadályozottak az átlagos 3 hibájuk közel 9\%-át javították, míg a kontrollcsoport átlagosan 1 hibát ejtett.

A szótagok olvasási tempóját legtöbb esetben csak a betük szintje elözi meg. A célcsoport átlagtempója $62 \mathrm{mp}$, míg a kontrollcsoporté 48,5 mp. A tanulásban akadályozottak az átlagos 8,4 számú hiba 17\%-át javították, míg a kontrollcsoport az átlagos 3,65 db hiba 33\%-át korrigálták.

Mindkét csoportban a szavak olvasása tart a leghosszabb ideig, és az átlagos hibaszám is itt a legmagasabb. A csoportok közötti minőségi különbségek ebben az esetben is megjelennek. A tanulásban akadályozottak átlagosan $92 \mathrm{mp}$ alatt olvasták el az $50 \mathrm{db}$ szót, 11 hibával, melynek csupán 14,5\%-át javították, míg a kontrollcsoport $62 \mathrm{mp}$-ig olvasta a szavakat, átlagosan 4 hibával melynek 40\%-át javították.

A szöveg olvasásának tempója a szavaknál valamivel gyorsabban, de a szótagoknál lassabban történik. A célcsoport átlaga $82 \mathrm{mp}$, míg a kontrollcsoporté $48 \mathrm{mp}$. A hibaszámok átlagmennyisége a tanulásban akadályozottaknál $8 \mathrm{db}$, melynek 10,5\%-át javították, míg a kontrollcsoportban a 2,7 hibaszám 14\%-át korrigálták.

Ha összevetjük ezeket az eredményeket az olvasás tempójával, azt tapasztalhatjuk, hogy amelyik területen a gyerekek többet időznek, ott nagyrészt több hibát is ejtenek, ahol pedig gyorsabban olvasnak, kevesebb az átlag hibaszám is.

A típushibák (1. táblázat) közül mindkét csoportnál a rossz kombináció a leggyakoribb, ezt követi a perszeveráció, vagyis a megtapadás, majd az elővételezés, negyedik helyen pedig a 
betűbetoldás áll. A tanulásban akadályozott gyerekek esetében a betűkihagyás is számottevő nehézségnek bizonyult.

1. táblázat - Az olvasástechnikai hibák elöfordulása (darab)
\begin{tabular}{|c|c|c|}
\hline & Tan.ak. & Kontroll \\
\hline Rossz kombináció (db) & 142 & 66 \\
\hline Perszeveráció (db) & 140 & 54 \\
\hline Elővételezés (db) & 90 & 37 \\
\hline Betübetoldás (db) & 69 & 28 \\
\hline Betükihagyás (db) & 61 & 19 \\
\hline Reverzió (db) & 33 & 13 \\
\hline Szóroncs (db) & 19 & 0 \\
\hline Szótagkihagyás (db) & 18 & 15 \\
\hline Szótagbetoldás (db) & 12 & 3 \\
\hline
\end{tabular}

Az olvasólap az olvasott szöveghez kapcsolódó öt kérdéssel vizsgálja a megértést. A tanulásban akadályozott gyerekek átlagosan 2,8 kérdésnél hibáztak, a kontrollcsoportban pedig átlagosan 2 értési hibájuk volt.

\section{Összefüggések a beszédfeldolgozás és olvasás mechanizmusa között}

A GMP2, GMP3, GMP4 és GMP5 altesztek átlaga adja a percepciós kvócienst (PQ) (2. ábra), amely a célcsoport $(71,35 \%)$ és a kontrollcsoport $(81,5)$ között nem mutat nagy eltérést. A PQ és az MQ, vagyis a szöveg- és mondatértés átlagát mutató megértési kvóciens között összefüggés feltételezhető, így összehasonlítottuk az egyes csoportok eredményeit, ezt mutatja be a 2. táblázat, melyben a megértés altesztjeit az észlelés átlagai alapján összesítettük. Leolvasható, hogy a tanulásban akadályozottak és a kontrollcsoport átlaga alatt és felett hogyan teljesítettek a tanulók. Az eredmények azt mutatják, hogy azok a gyermekek, akiknek alacsonyabb a percepciós kvóciensük, tartozzon akár a célcsoporthoz, akár a kontrollcsoporthoz, a megértésük szintje is alacsonyabb.

2. táblázat - A percepciós kvóciens és a megértési kvóciens közti összefüggések

\begin{tabular}{|c|c|c|c|}
\hline \multicolumn{2}{|c|}{ Tan.ak. } & \multicolumn{2}{c|}{ Kontroll } \\
\hline & MQ átlag & MQ átlag \\
\hline PQ 70\% alatt (9fó) & $66 \%$ & PQ 70\% alatt (2 fö) & $72,5 \%$ \\
\hline PQ 70-80\% (12 fö) & $64 \%$ & PQ 70-80\% (11 fö) & $81 \%$ \\
\hline PQ 81-100\% (5 fó) & $77 \%$ & PQ 81-100 (12 fö) & $88 \%$ \\
\hline
\end{tabular}

A Pearson-féle korrelációanalízis a tipikus fejlődésütemü gyermekek esetében gyenge kapcsolatot $(r=.346)$ eredményezett a beszédészlelés és beszédmegértés között 95\%-os szignifikanciaszinten. A tanulásban akadályozott tanulók esetében a beszédészlelés és beszédmegértés között erősebb kapcsolatot $(r=.451)$ igazol a vizsgálat.

A kontrollcsoportban 5 fö van, aki egyenlöen teljesített a GMP12 és GMP16-os altesztekben, és 2 fö, akiknél a szövegértés szintje 10\%-kal magasabb, mint a mondatértés. Ebből a 7 főböl csupán 3 gyermek PQ-ja volt 80\% fölötti. A tanulásban akadályozottak között 2 fö volt, aki a két megértési altesztben egyenlő eredményt produkált, mindenki másnál a mondatértés magasabb szintü volt, mint a szövegértés. Az ő PQ-juk 60\% és $80 \%$. 
Az olvasástechnikai összefüggéseket a megértés oldaláról közelítettük meg, vagyis, hogy van-e bármilyen kapcsolat az olvasási tempó, a hibaszám és a megértés között. Egyik csoportban sem figyelhető meg egyenletes változás az adatok között. Tanulásban akadályozottaknál azok a gyerekek olvastak a legtovább és legtöbb hibával, akiknek 4 értési hibájuk volt, míg leggyorsabban és legkevesebb hibával azok, akiknek 2 értési hibájuk volt. A kontrollcsoport esetében leggyorsabban és legkevesebb hibával azok olvastak, akik minden megértést vizsgáló kérdésre helyesen válaszoltak, viszont leglassabban és a legtöbb hibával a 3 kérdésre rosszul válaszolók olvastak. Az olvasástechnikai hibák mennyisége a célcsoportnál az értési hibákkal párhuzamosan növekszik, ám a legtöbb helytelen választ adóknál lecsökken. Hasonló tendencia figyelhető meg a kontrollcsoportban is, ám ott a hibaszámok csökkenése a 2 értési hibával rendelkezöknél figyelhető meg.

A beszédfeldolgozás és az olvasás mechanizmusa közötti összefüggések a percepciós görbék segítségével határozhatók meg. A tanulásban akadályozottak percepciós teljesítménye alapján a fordított teknő típusú észlelési elmaradás tapasztalható (3. ábra). Erre a típusra jellemző a gyenge szeriális és szövegértési teljesítmény, illetve a határértéken túli olvasástechnikai- és olvasott szövegértési hiba. Az akusztikai és a fonológiai észlelés alacsony teljesítménye is nagyobb arányban jelenhet meg.

A kontrollcsoport percepciós átlaga szerint a hegyvonulat típusú zavartípus rajzolódik ki (3. ábra). Ennél a zavartípusnál a fonetikai észleléshez képest a többi észlelési folyamat gyengébben müködik, és további nehézséget jelenthet a fonológiai és szeriális észlelés, a szövegértés, valamint az olvasási probléma.

Vizsgáltuk továbbá a szeriális észlelés és az olvasástechnikában megjelenő reverziós hibák előfordulási gyakoriságát, illetve ezek összefüggéseit (3. táblázat). A kontrollcsoportban nincs jelentős különbség a szeriális észlelés eredményében attól függően, hogy az olvasásában előfordult-e a gyermeknél a reverziós hibatípus, azonban a tanulásban akadályozottak közül közel 10\%-kal jobban teljesítettek azok, akiknél nem volt reverziós tévesztés.

3. táblázat - A szeriális észlelés és a reverziós olvasástechnikai hibák közti összefüggések

\begin{tabular}{|c|c|c|}
\hline & $\begin{array}{c}\text { GMP10 átlageredménye } \\
\text { reverziós hibával }\end{array}$ & $\begin{array}{c}\text { GMP10 átlageredménye } \\
\text { reverziós hiba nélkül }\end{array}$ \\
\hline Tan.ak. & $47,7 \%$ & $59 \%$ \\
\hline Kontroll & $90 \%$ & $86 \%$ \\
\hline
\end{tabular}

A tipikusan fejlődő tanulók eredménye alapján a beszédfeldolgozás és olvasási készség között a következö összefüggések fogalmazhatók meg: a Pearson-féle korrelációanalízis 95\%os szignifikanciaszinten a beszédészlelés és olvasási készség között gyenge $(\mathrm{r}=.329)$ kapcsolatot eredményezett. A beszédészlelés és olvasási készség, illetve a beszédmegértés és az olvasási készség összefüggése nem volt igazolható. A tanulásban akadályozott tanulók esetében a vizsgálat beszédészlelés és olvasási készség között gyenge ( $\mathrm{r}=.367)$ kapcsolatot eredményezett. A beszédmegértés és az olvasási készség összefüggése nem volt igazolható.

A beszédfeldolgozás elemeit és az olvasási készség szintjeit vizsgálva a tipikus fejlődésü gyermekek esetében a Pearson-féle korrelációanalízis nem igazolt összefüggést. A tanulásban akadályozott tanulók esetében a feldolgozás és az olvasás minőségének kapcsolata kirajzolódik az összefüggések feltárása során. Az akusztikai észlelés gyenge összefüggést mutat a szóolvasás $(r=.411)$ és szövegolvasás $(r=.398)$ eredményével, a fonetikai észlelés szintén gyenge összefüggést mutat a szóolvasási $(r=.401)$ és szövegolvasási $(r=.399)$ teljesítménnyel. A fonológiai észlelés gyenge kapcsolatot mutat a szótagolvasás készségével $(r=.399)$. A szeriális észlelés a szótagolvasás $(r=.431)$, a szóolvasás $(r=.490)$ és a szövegolvasás $(r=.398)$ eredményével mutat gyenge összefüggést 95\%-os 
szignifikanciaszinten. A mondat- és szövegértés összefüggését az olvasás különböző szintü készségével a statisztikai próba nem igazolta.

\section{MEGVITATÁS}

Hipotéziseinknek megfelelően a következők fogalmazhatók meg. Jelen kutatás alátámasztja azt a feltételezést, miszerint az integrált keretek között oktatott, tanulásban akadályozott gyerekek mellett (Macher, 2013) a szegregáltan oktatott, 3-4. évfolyamos tanulók is súlyos elmaradásokat mutatnak a beszédfeldolgozás minden vizsgált szintjén, a kontrollcsoport eredményéhez viszonyítva szignifikánsan gyengébben teljesítenek. A célcsoport tagjai a sztenderd eredményekhez viszonyítva körülbelül átlagosan 7 éves elmaradást mutatnak. A beszédészlelés szintjei közül az akusztikai szint müködése a legbiztosabb, a fonológiai szint a leggyengébben müködő, a célcsoportnál az elvárhatóhoz képest 8,5 éves elmaradást mutat. A komponensek közötti összefüggések rámutattak arra, hogy a fonológiai szint müködése közepesen erös együttjárást mutat az akusztikai és fonetikai feldolgozással. Ilyen összefüggés a tipikusan fejlödő gyermekek esetében nem volt igazolható. Feltételezésünknek megfelelően a beszédmegértés két vizsgált eleme közül a mondatok feldolgozása jelentett kevesebb nehézséget mind a tanulásban akadályozott, mind a tipikusan fejlödő tanulók számára. A mondatértés magasabb szintü müködését találta Macher (2007, 2013) 7 és 10 éves tanulásban akadályozott gyerekek körében, illetve Markó (2007) 69 éves tipikus fejlődésü gyermekeknél is. A tipikusan fejlődő gyermekekétől eltérően a feldolgozás különböző szintjei között a vizsgálat számos, jellemzően közepesen erős összefüggést igazolt a célcsoportban. A megértésben föként az összefüggések megértésére vonatkozó kérdések jelentettek nehézséget a tanulóknak.

A beszédészlelés és a beszédmegértés müködésmechanizmusa között is egyértelmü kapcsolat áll fenn, amelyet statisztikai vizsgálat igazolt.

Az olvasási készséggel kapcsolatban megfogalmazható, hogy a tanulási akadályokkal küzdő tanulók mind a betü-, szótag-, szó- és szövegolvasás minőségében jelentős eltérést, szignifikánsan gyengébb teljesítményt nyújtanak a tipikusan fejlödő gyermekekhez képest. Az eredmények megfelelnek a korábbi empirikus eredményeknek (Papp, 2010; Józsa és tsai, 2014). A tanulásban akadályozottak 85\%-a nevezhető gyengén olvasónak az olvasólap sztenderd eredményei alapján. Az olvasás különböző szintjei között a beszédfeldolgozás szintjeinek együttjárásához hasonló eredmények nem voltak igazolhatók. Az olvasási tempó a betük szintjén a leggyorsabb, továbbá a legkevesebb hiba és legjobb hiba javítási arány is itt mutatkozott. Ennek több oka is lehet. Egyrészt a betük ismerete 3-4. évfolyamra már bevésődött és az olvasása készségszintüre fejlődött, illetve az olvasás megszokott iránya is pozitívan befolyásolhatta a tempót, hiszen a szótagok és szavak olvasása során függőleges oszlopok szerint kellett haladniuk.

Egyfajta felnőtt olvasási rutinnak a kialakulása mindkét csoportnál megfigyelhető a szavak és a szöveg szintjén. Ezt támasztja alá a rossz kombinációk gyakoribb megjelenése a felsorolt szinteken, mely következményeként megnövekszik a nem meghatározható betütévesztések mennyisége is. A tanulásban akadályozott gyerekeknél is az életkori sajátosságnak megfelelően elkezd kialakulni egy magasabb minőségü olvasási gyakorlat, ám olvasástechnikájuk még nem kellően biztos, így a kombinációkkal történő kompenzáció hibás olvasást eredményez, amely a megértést is nehezíti.

A tanulásban akadályozottak körében sokkal nagyobb arányban találkozhatunk a vizuális és a fonetikus hasonlóságon alapuló, illetve ezek kombinációjából eredő betütévesztésekkel, amely szintén elörevetíti a súlyosabb olvasási nehézségeket és azok korrigálásának nehézségeit. A vizuális tévesztések hátterében főleg a tájékozódási problémák, az iránytévesztés nehézsége, vagy akár az oldaliság kialakulatlansága is állhat, míg a fonetikus mögött artikulációs és beszédészlelési nehézségek jelenhetnek meg. Ezek kombinált 
elöfordulása rendkívül makacs és sok területet érintő problémát feltételez, melynek javítása hosszú időt vehet igénybe.

Feltételezésünk, miszerint a súlyos beszédpercepciós elmaradás az olvasás minőségében és a szövegértésben is jelentős nehézséget jelent, beigazolódott. A kutatási eredmények alapján a beszédpercepciós és az olvasási képességek minősége között jellemzően közepes erősségü összefüggés mérhető. A kontrollcsoportban ilyen együttjárásokat nem igazolt a vizsgálat.

Valószínüsítettük továbbá, hogy hasonló hibatípusok fordulnak elő a hallott és olvasott információk feldolgozása esetében.

Ezt igazolja a percepciós görbék és az olvasólapon előforduló gyengébb teljesítmények közti kapcsolat. A szeriális észlelés problémáját jelzi a hegyvonulat, a háztető, és a fordított teknö görbéje, míg a szövegértését a hegyvonulat, a csökkenő és a forditott teknö. Az olvasás területén a magas hibaszámmal kapcsolatban állhat a hegyvonulat, a háztető és a fordított teknö, a tempóval kapcsolatos elmaradásokat pedig a háztetö. Az olvasott szöveg megértésének hibáival a háztető és a forditott teknő típusú görbe áll kapcsolatban. Horváth (2007) kutatásában a szeriális észlelés nehézségeit gyakoribbnak találta a csökkenő típusú görbe esetén, szövegértési problémát vetíthet elöre a forditott teknö, a csökkenö és a fürészfog típusú vonulat, illetve az olvasás nehézségeivel kapcsolatban állhat szintén a forditott teknö, a csökkenö görbe és a hegyvonulat.

A tanulásban akadályozottak percepciós átlaga alapján a forditott teknő típusú észlelési elmaradás tapasztalható. Horváth (2007) szerint ez a leggyakoribb típus, mely a kutatásában résztvevő tipikus fejlődésű gyerekek közel 30\%-ára jellemző. A görbe alakja szerint az akusztikai észlelés jobb, mint a leggyengébbnek mutatkozó fonológiai észlelés, s a legjobb eredményt a fonetikai észlelés területén érik el a gyerekek. Azok azonban, akiknek a fonológiai észlelése $20 \%$-os, vagy az alatti, nagyon súlyos zavarral küzdenek.

A beszédfeldolgozás részfolyamatai közül a szeriális észlelés kapcsolatban állhat az olvasásban megjelenő reverziós hibákkal, hiszen azok a gyerekek, akik reverziós tévesztésekkel olvastak, gyengébben teljesítettek a GMP10 altesztben. A vizsgálat eredményei alapján a beszédészlelés minősége közepesen erősen összefügg a szóolvasó, szövegolvasó és szövegértő képességgel. A beszédmegértés esetében ilyen hatás nem volt igazolható.

\section{KORLÁTOZÁSOK, KONKLÚZIÓK}

A kutatás több szempontból is korlátok közé szorult. A minta elemszámának bővítésével az eredmények erőteljesebb elhatárolódása valósulhatott volna meg, melynek hátránya leginkább a beszédfeldolgozás eredményeinek feldolgozásakor volt érezhető. A mintabővítés történhetne több országrészt felölelve, vagy akár más osztályfokokra kiterjesztve. A sztenderdizált tesztek ismertsége és több más területen való alkalmazása abból a szempontból jelentett hátrányt, hogy néhány gyermek már ismerhette a feladatokat, ez azonban kevéssé kiküszöbölhető probléma, ugyanis a gyógypedagógusok a hivatalos kontrollvizsgálatok során is ugyanezeket az eszközöket alkalmazzák. Az itt elemzett készségeket más vizsgálóeljárások eredményeivel összevetni szintén szükséges lehet későbbi kutatásokban.

A vizsgálat eredményei felhívják a figyelmet arra, hogy a beszédfeldolgozás és olvasás terén tapasztalt elmaradásokkal a tanulásban akadályozott tanulók mellett a tipikus fejlődésütemü gyerekek egyaránt küzdenek.

A beszédfeldolgozás súlyos és általános elmaradása többek között arra is figyelmeztet, hogy nem csak a tanulásban akadályozott gyermekekkel foglalkozó gyógypedagógusok, hanem minden pedagógus, sőt, a szülők figyelmét is fel kell hívni a problémára, hiszen a készség nem megfelelő szintü müködése nemcsak iskolai életben, hanem a mindennapokban 
is hátrány. Szükséges lenne nagy hangsúlyt helyezni a prevencióra, amely akár már óvodáskorban megkezdődhetne, illetve az oktató-nevelö munkát érintő módszerek megváltoztatására, így a frontális oktatás és az egyéni munka háttérbe szorítására, helyettük pedig a kooperatív-, és projektmódszer, valamint az élménypedagógia előtérbe helyezésére. A beszédfeldolgozásban nehézséget mutatók esetében az összefüggések meglátása problémás, a gondolkodás müveletei is érintettek, feltételezhető a logikus-, a következtetö-, az analógiás-, az analitikus és szintetikus gondolkodás alacsonyabb szintje. A mondatértés elmaradása könnyen eredményezheti a szóban elhangzó feladatok- és utasítások megértésének nehezítettségét. A tanulásban akadályozott gyerekek megértésének minden vizsgált szintje jelentősen akadályozott, amely nagymértékben megnehezíti az iskolában való megfelelést, így nem csak a szóbeli utasítások, de a hosszabb magyarázatok megértése is korlátozott.

A beszédészlelés célzott fejlesztését be kellene építeni az egyes tantárgyakba, és mindenképpen időt kellene szánni az erősítésére, hiszen a befektetett energia többszörösen is megtérülne, s számos más terület, például az olvasási- és a szövegértési képesség súlyos elmaradását kiküszöbölhetné. A szoros együttjárások bizonyítják, hogy a fejlődési folyamat során erőteljes transzferhatás várható a feldolgozás szintjei és az olvasás minősége között. Mindez a komplex fejlesztést indokolja, magasabb évfolyamokon is.

A szeriális észlelés elsősorban az olvasástechnika minőségét befolyásolja, így annak fejlesztése - nemcsak az olvasás előkészítő szakaszában - kellene, hogy kiemelt feladat legyen. Mivel a sorrendiség megfelelő azonosításának alapja a ritmus érzékelése és észlelése, ezért érdemes lenne minél alacsonyabb életkorban elkezdeni a fejlesztését, melynek mindenképpen a mozgás adna megfelelö teret, amely kiegészülhetne a zenés foglalkozások ritmust fejlesztő tevékenységeivel, amelyek az anyanyelvi fejlesztéshez igen jól kapcsolhatók.

Kiemelendő az olvasottak megértését támogató hatékony olvasási stratégiák tanításának szerepe, amely az olvasás tanításával párhuzamosan kellene, hogy minden életkorban szerepet kapjon.

A továbbiakban érdemes lehetne más osztályfokokon, esetleg felső tagozaton is elvégezni a vizsgálatokat, hogy az életkori fejlödés is kimutathatóvá váljon, továbbá más, a beszédfeldolgozáshoz szükséges részfolyamatok elvégzése is hasznos összefüggésekre deríthetne fényt. A hallott- és olvasott szövegértés kiegészülhetne a néma olvasás utáni szövegértéssel, és a megértést még a szóértés vizsgálatával is lehetne bővíteni. Mindezen túl a helyesírás és a beszédfeldolgozás közti kapcsolatok felderítése is nagyon érdekes kutatási téma lehetne.

Mindezek az eredmények, és felmerülő újabb kutatási témák azt mutatják, hogy a beszédészlelés és beszédfeldolgozás számos más készség és képesség alapkövét alkotja, vagy befolyásolja azt, így a továbbiakban még számos vizsgálatra van szükség ahhoz, hogy ezek az összefüggések pontosan kirajzolódjanak és átláthatóvá váljanak.

\section{Felhasznált irodalom}

Adamikné Jászó A. (1996). A beszédpercepció fejlettségének szerepe az olvasás-írás elsajátításában és tanításában. In Gósy M. (szerk.). Gyermekkori beszédészlelési és beszédmegértési zavarok. (pp. 222-243). Budapest: Nikol Kkt.

Blomert, L. és Csépe V. (2012). Az olvasástanulás és -mérés pszichológiai alapjai In Csapó B. és Csépe V. (szerk.). Tartalmi keretek az olvasás diagnosztikus értékeléséhez. (pp. 17-86). Budapest: Nemzeti Tankönyvkiadó.

Bóna J. (2007). A fonológiai és a szeriális észlelés fejlödése 4-10 éves korban. In Gósy M. (szerk.). Beszédészlelési és beszédmegértési zavarok az anyanyelv-elsajátitásban. (pp. 262270). Budapest: Nikol Kkt. 
Channell, M., Loveall, S. J. és Conners, F. A. (2013). Strengths and weaknesses in reading skills of youth with intellectual disabilities. Res Dev Disabil, (2), 776-787.

Chiappe, P., Chiappe, D. L., Siegel, L. S. (2001). Speech Perception, Lexicality, and Reading Skill. Journal of Experimental Child Psychology, 80., (pp. 58-74). Letöltés helye: http://www.sciencedirect.com/science/article/pii/S0022096500926249

Csépe V. (2007). A beszédészlelés kritikus kérdései és a beszédészlelés fejlődése „neuro”nézetből. In Gósy M. (szerk.). Beszédészlelési és beszédmegértési zavarok az anyanyelvelsajátításban. (pp. 20-43). Budapest: Nikol Kkt.

Csépe V., Győri M. és Ragó A. (2007-2008a) Általános pszichológia 1-3. - 3. Nyelv, tudat, gondolkodás. h. n., k. n.

Csépe V., Győri M. és Ragó A. (2007-2008b) Általános pszichológia 1-3. - 1. Észlelés és figyelem. h. n., k. n.

Fazekasné F. M. (2006). Az akusztikus és a vizuális észlelés szerepe az olvasástanulásban. In Józsa K. (szerk.). Az olvasási képesség fejlödése és fejlesztése. (pp. 189-206). Budapest: Dinasztia Tankönyvkiadó.

Gósy M. (1995). A beszédészlelési és beszédmegértési folyamat zavarai és terápiája. Budapest: ELTE BGGYFK.

Gósy M. (2000). A hallástól a tanulásig. Budapest: Nikol Kkt.

Gósy M. (2005). Pszicholingvisztika. Budapest: Osiris Kiadó.

Gósy M. (2006). GMP-diagnosztika. A beszédészlelés és a beszédmegértés folyamatának vizsgálata, fejlesztési javaslatok. Budapest: Nikol Kkt.

Gósy M. (2007a). Az anyanyelv-elsajátítás folyamatairól In Gósy (szerk.). Beszédészlelési és beszédmegértési zavarok az anyanyelv-elsajátításban. (pp. 8-18). Budapest: Nikol Kkt.

Gósy M. (2007b). Az értelmi képesség és a beszédpercepciós folyamatok összefüggései. In Gósy M. (szerk.). Beszédészlelési és beszédmegértési zavarok az anyanyelv-elsajátításban. (pp. 230-246). Budapest: Nikol Kkt.

Gósy M. és Horváth V. (2007). Óvodások és olvasási nehézséggel küzdő kisiskolások beszédhallása. In Gósy M. (szerk.). Beszédészlelési és beszédmegértési zavarok az anyanyelvelsajátításban. (pp. 84-103). Budapest: Nikol Kkt.

Gráczi T. E. (2007). Diszlexiás és tipikus fejlődésű gyermekek beszédfeldolgozásának vizsgálata. In Gósy M. (szerk.). Beszédészlelési és beszédmegértési zavarok az anyanyelvelsajátításban. (pp. 202-213). Budapest: Nikol Kkt.

Horváth V. (2007). Beszédészlelési folyamatok tipológiája 6-10 éves korban. In: Gósy M. (szerk.). Beszédészlelési és beszédmegértési zavarok az anyanyelv-elsajátitásban. Budapest: Nikol Kkt.

Horváth V. és Gyarmathy D. (2010). A beszédhallás szerepe a beszédhangdifferenciálásban. Gyógypedagógiai Szemle (2), 126-135.

Imre A. (2007). A beszédmegértés és az olvasás összefüggése. In Gósy M. (szerk.). Beszédészlelési és beszédmegértési zavarok az anyanyelv-elsajátitásban. (pp. 184-201). Budapest: Nikol Kkt.

Józsa K., Fazekasné Fenyvesi M., Szenczi B. és Szabó Á. (2014). Tanulásban akadályozott és tipikusan fejlődő gyermekek szóolvasási készségének, szövegértésének és olvasási motivációjának fejlődése. Magyar Pszichológiai Szemle (1) 181-204.

Macher M. (2007). Tanulásban akadályozott gyerekek beszédészlelési és beszédmegértési vizsgálata. In Gósy M. (szerk.). Beszédészlelési és beszédmegértési zavarok az anyanyelvelsajátitásban. (pp. 247-260). Budapest: Nikol Kkt.

Macher M. (2012). Tanulásban akadályozott gyermekek beszédészlelésének és beszédmegértésének diagnosztizálása. In Zajdó K. (szekcióvezetö) Az élethosszig tartó gyógypedagógiai ellátás lehetőségei és korlátai egy idősödö társadalomban. XVI. Apáczai- 
napok Tudományos konferencia előadásaiból készült tanulmánykötet. Letöltés helye: http://www.ak.nyme.hu/index.php?id=24236 (2017.02.05.)

Macher M. (2013). Beszédpercepciós és szóaktiválási folyamatok elemzése tanulásban akadályozott gyermekeknél. Doktori disszertáció. h. n., k. n.

Markó A. (2007). A mondat- és szövegértés jellemzői és összefüggése 6-9 éves korban. In Gósy M. (szerk.). Beszédészlelési és beszédmegértési zavarok az anyanyelv-elsajátitásban. (pp. 285-300). Budapest: Nikol Kkt.

Meixner Alapítvány (2016). Vizsgálati útmutató a 3. évfolyamosok vizsgálatára szolgáló Meixner-olvasólap használatához és kiértékeléséhez. Budapest: Meixner Alapítvány.

Meixner I. (1995). Munkásságom tézis-szerü összefoglalása Letöltés helye: http://www.diszlexia.info/mexinertezis.htm

Mesterházi Zs. (1998). A nehezen tanuló gyermekek iskolai nevelése. Budapest: Bárczi Gusztáv Gyógypedagógiai Tanárképző Főiskola.

Nagy J. (2004). Olvasástanítás: a megoldás stratégiai kérdései. Iskolakultúra (3) 3-25.

Nagy J. (2006). Olvasástanítás: A megoldás stratégiai kérdései. In Józsa K. (szerk.). $A z$ olvasási képesség fejlödése és fejlesztése. (pp. 17-42). Budapest: Dinasztia Tankönyvkiadó.

Papp G. (2010). A tanulásban akadályozott tanulók és az olvasás. Olvasáspedagógia (XII/1)

Papp G. (2011). Tanulásban akadályozott tanulók és az olvasás. Magyartanítás. (3) 12-15.

Pléh Cs. és Lukács Á. (2014). Pszicholingvisztika I. Budapest: Akadámiai Kiadó.

Putter-Katz, H., Banai, K. és Ahissar, M. (2005). Speech Perception in Noise among Learning Disabled Teenagers. In Syka, J. és Merzenich M. M. (szerk.). Plasticity and Signal Representation int he Auditory System. (pp. 251-257). h. n. Springer Science \& Business Media. Letöltés helye: https://www.researchgate.net/publication/ 226263625_Speech_Perception__in_Noise_among_Learning_Disabled_Teenagers (2017. február 18.)

Sipos Zs. (2017). A 3. évfolyamosok olvasásának vizsgálatára kidolgozott Meixnerolvasólap sztenderdizálásának első eredményei. Gyógypedagógiai Szemle (1) 47-58.

Snellings, P., Van der Leij, A., Blok, H. és Jong P. F. (2010). Reading fluency and speech perception speed og beginning readers with persistent reading problems: the perception of initial stop consonants and consonant clusters. Ann. of Dyslexia. 60., 151-174. 